medRxiv preprint doi: https://doi.org/10.1101/2021.01.27.21250590; this version posted January 29, 2021. The copyright holder for this preprint (which was not certified by peer review) is the author/funder, who has granted medRxiv a license to display the preprint in

It is made available under a CC-BY-NC-ND 4.0 International license .

\title{
RNA sequencing of a large number of psoriatic patients identifies 131 novel miRNAs and 11 miRNAs associated with disease severity
}

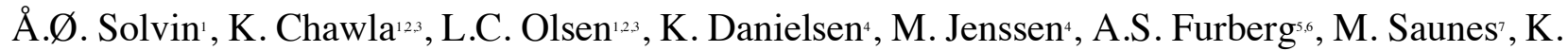 \\ Hveem $^{1.8}$, P. Sætrom ${ }^{12,39}$, M. Løset ${ }^{1.7}$
}

'K.G. Jebsen Center for Genetic Epidemiology, Department of Public Health and Nursing, NTNU, Norwegian University of Science and Technology, Trondheim, Norway

Department of Clinical and Molecular Medicine, NTNU, Norwegian University of Science and Technology, Trondheim, Norway

Bioinformatics Core Facility, NTNU, Norwegian University of Science and Technology, Trondheim,

Norway

Department of Dermatology, University Hospital of North Norway, Troms $\varnothing$, Norway

sDepartment of Community Medicine, Faculty of Health Sciences, UiT The Arctic University of Norway,

Troms $\emptyset$, Norway

Department of Microbiology and Infection Control, University Hospital of North Norway, Troms $\varnothing$, Norway

Department of Dermatology, Clinic of Orthopaedy, Rheumatology and Dermatology, St. Olavs hospital,

Trondheim University Hospital, Trondheim, Norway

sHUNT Research Centre, Department of Public Health and Nursing, NTNU, Norwegian University of

Science and Technology, Trondheim, Norway

Department of Computer Science, NTNU, Norwegian University of Science and Technology, Trondheim,

Norway

\section{Corresponding Author:}

Mari Løset, MD, PhD

K.G. Jebsen Center for Genetic Epidemiology

Department of Public Health and Nursing

NTNU, Norwegian University of Science and Technology

Postboks 8905

N-7491 Trondheim, Norway

Tel: +4790799117

E-mail: mari.loset@ntnu.no/mari.loset@stolav.no

\section{Conflicts of interest}

None declared.

\section{Funding sources}

ML, PS, KH, KC and LCO work in a research unit funded by Stiftelsen Kristian Gerhard Jebsen; Faculty of Medicine and Health Sciences, NTNU; The Liaison Committee for education, research and innovation in Central Norway; and the Joint Research Committee between St. Olavs hospital and the Faculty of Medicine and Health Sciences, NTNU. ML was supported by a research grant from the Liaison Committee for education, research and innovation in Central Norway. The funders had no influence on study design, data collection and analysis, decision to publish, or preparation of the manuscript. 
medRxiv preprint doi: https://doi.org/10.1101/2021.01.27.21250590; this version posted January 29, 2021. The copyright holder for this preprint (which was not certified by peer review) is the author/funder, who has granted medRxiv a license to display the preprint in It is made available under a CC-BY-NC-ND 4.0 International license .

\begin{abstract}
Background: MicroRNAs are small regulatory molecules that are dysregulated in psoriasis. Despite previous efforts, much is unknown about the regulatory mechanisms of psoriasis genetics and their contributions to disease development and activity.
\end{abstract}

Objectives: To globally characterize the miRNAome of psoriatic skin in a large sample of psoriatic cases and controls for increased understanding of psoriasis pathophysiology.

Methods: Skin biopsies from psoriatic cases $(n=75)$ and non-psoriatic controls $(n=57)$ were RNA sequenced. Count data was meta-analyzed with a previously published dataset (cases, $\mathrm{n}=24$, controls, $\mathrm{n}=20$ ), increasing the number of psoriatic cases four-fold from previously published studies. Differential expression analyses were performed comparing lesional psoriatic (PP), non-lesional psoriatic (PN) and control (NN) skin. Further, functional enrichment and cell specific analyses were performed.

Results: We identified 439 significantly differentially expressed miRNAs (DEMs), of which 131 were novel and 11 were related to disease severity. Meta-analyses identified 20 DEMs between PN and NN, suggesting an inherent change in all psoriatic skin. By integrating the miRNA transcriptome with mRNA target interactions, we identified several functionally enriched terms, including 'thyroid hormone signaling', 'insulin resistance' and various infectious diseases. Cell specific expression analyses revealed that the upregulated DEMs were enriched in epithelial and immune cells.

Conclusions: We have provided the most comprehensive overview of the miRNome in psoriatic skin to date and identified a miRNA signature related to psoriasis severity. Our results may represent molecular links between psoriasis and related comorbidities and have outlined potential directions for future functional studies to identify biomarkers and treatment targets. 
medRxiv preprint doi: https://doi.org/10.1101/2021.01.27.21250590; this version posted January 29, 2021. The copyright holder for this preprint (which was not certified by peer review) is the author/funder, who has granted medRxiv a license to display the preprint in It is made available under a CC-BY-NC-ND 4.0 International license .

\section{Introduction}

Psoriasis is a complex disease, triggered by environmental factors in genetically susceptible individuals. The prevalence is substantially higher in the Nordic countries ${ }^{1.3}$ compared to global estimates ${ }^{4}$. Genomic studies have established psoriasis as a Th-17/IL-23 dominated disease ${ }^{5}$ and guided development of novel treatments s. However, the exact pathophysiological mechanisms are unknown, and the regulatory mechanisms of psoriasis genetics have not yet been fully explained.

MicroRNAs (miRNAs) are non-coding RNAs, contributing to post-transcriptional downregulation of gene expression by repressing or degrading their target messenger RNAs (mRNAs) ${ }^{6}$. More than $60 \%$ of human mRNAs contain evolutionary conserved miRNA target sites, suggesting that miRNAs can have a profound impact on cellular states and disease phenotypes ' ${ }^{7}$ The first psoriasis-specific miRNAs were published in $2007^{\circ}$. With increasing sample sizes, advancing technologies and analytical methods, several differentially expressed miRNAs (DEMs) have since been identified ${ }^{8-14}$. Targeted characterization has shown that many of these DEMs play central roles in regulating cellular functions and miRNAs have been suggested as sensitive biomarkers for disease activity, prognosis and treatment response ${ }^{15}$. However, previous studies have involved a relatively small number of skin samples, some did not include a control group and the majority have employed microarrays rather than next-generation sequencing (NGS). For the study with the largest reported sample size to date (psoriatic cases, $\mathrm{n}=24$ ) ", we found the reproducibility of the reported miRNAs unclear, most likely due to their choice of statistical approach.

To comprehensively profile the psoriasis miRNAome, we used high-resolution RNA sequencing (RNAseq) of a large number of lesional psoriatic (PP), non-lesional psoriatic (PN) and control skin (NN) skin from 121 individuals (cases, $n=75$, controls, $n=46$ ). To increase the power to detect novel DEMs, we did a robust statistical re-analysis of the largest dataset published to date (GSE31037)" and meta-analyzed this with our data. The meta-analysis included 99 psoriatic cases and 66 non-psoriatic controls, increasing the number of psoriatic cases four-fold from previously published studies on miRNAs in psoriasis.

\section{Patients and methods}

\section{Participants and skin samples}

Participants were adults of European descent. Psoriatic cases had psoriasis vulgaris and underwent a wash-out period without any topical or systemic-/photoherapy for two and four weeks prior to participation, respectively. Controls did not have psoriasis or any other inflammatory skin disease, nor any first-degree relatives with psoriasis. Disease severity was assessed using Psoriasis Area and 
medRxiv preprint doi: https://doi.org/10.1101/2021.01.27.21250590; this version posted January 29, 2021. The copyright holder for this preprint (which was not certified by peer review) is the author/funder, who has granted medRxiv a license to display the preprint in It is made available under a CC-BY-NC-ND 4.0 International license .

Severity Index (PASI). From cases, two 4mm skin biopsies were collected; one PP and one PN. From controls one $4 \mathrm{~mm}$ biopsy $\mathrm{NN}$ was collected. If possible, the PN and $\mathrm{NN}$ samples were taken from a sun-protected area on the buttock. Biopsies were snap frozen in liquid nitrogen and later stored at $80^{\circ} \mathrm{C}$. Written informed consent was obtained from all participants. The study was approved by the Regional Committee for Medical and Health Research Ethics in Mid-Norway and conducted according to the Declaration of Helsinki principles.

\section{Total RNA extraction, library preparation and RNA sequencing}

Skin biopsies were homogenized using Precellys homogenizer (Bertin Technologies, USA) and RNA was extracted using mirVana Isolation Kit (Applied Biosystems, Foster City, CA, USA). RNA integrity (RIN) was assessed using the Agilent RNA 6000 Nano kit on a 2100 Bioanalyzer chip (Agilent Technologies, Inc., Santa Clara, CA, USA) and the mean RIN was 8.2. Sequencing libraries were prepared using the NEXTflex small RNA-seq kit v3 (Bio Scientific, Austin, TX, USA). Singleend read sequencing was performed on an Illumina HiSeq4000 instrument, in accordance with the manufacturer's instructions (Illumina, Inc., San Diego, CA, USA). The reads were mapped to human miRNAs in the miRBase database $v 22.1{ }^{16}$ with the miraligner tool ${ }^{17}$.

\section{Differential expression analysis}

We identified DEMs in our samples (henceforth; the NTNU dataset) across three contrasts (PP versus NN, PP versus PN and PN versus NN) using a linear model adjusted for sex, age and BMI. The count matrices were transformed using the voom algorithm from the limma package of Bioconductor ${ }^{18.19}$. The Benjamini-Hochberg method ${ }^{20}$ was used to control the false discovery rate (FDR), and miRNAs with FDR $<0.05$ were considered significantly differentially expressed. We reanalyzed the hitherto largest published miRNA dataset in psoriatic skin (NCBI GEO accession number: GSE31037) (henceforth; the Joyce dataset)", using the same statistical approach as on the NTNU dataset before meta-analysis. The meta-analysis included an additional factor estimating expression differences between the two datasets in the linear model. To determine if any miRNAs were related to psoriasis severity, cases were separated into mild (PASI $<10)$ and moderate/severe (PASI $\geq 10$ ) disease before differential expression analysis.

\section{Target prediction and functional enrichment analysis}

Target genes for the top 20 most up- and downregulated DEMs were identified using the TargetScan database ${ }^{21}$. Functional enrichment of Kyoto Encyclopedia of Genes and Genomes (KEGG) terms was performed using the gProfileR package in $\mathrm{R}^{22}$. DEMs associated with psoriasis severity were analyzed for enrichment of Reactome terms ${ }^{23}$ using the online tool miRnet (www.mirnet.ca) ${ }^{2425}$. 
medRxiv preprint doi: https://doi.org/10.1101/2021.01.27.21250590; this version posted January 29, 2021. The copyright holder for this preprint (which was not certified by peer review) is the author/funder, who has granted medRxiv a license to display the preprint in It is made available under a CC-BY-NC-ND 4.0 International license .

\section{Cell and tissue specific expression analysis}

The FANTOM5 atlas ${ }^{26}$ was used to determine which cells express the top 10 most up- and downregulated DEMs by fold change (FC) in the meta-analysis, both overall and after PASI stratification.

\section{Results}

Study participants

A total of 75 psoriatic cases and 46 controls were enrolled in the study. Clinical characteristics are presented in Table 1.

\section{Differentially expressed miRNAs}

In PP/NN, we identified 375 DEMs in the NTNU dataset, 231 DEMs in the Joyce dataset and 395 DEMs in the meta-analysis (FDR $<0.05, \log _{2} \mathrm{FC}>0$ ) (Table 2, supplementary table (ST) 1-3). In PP/PN, we identified 415, 225 and 401 DEMs in the NTNU, Joyce and meta-analysis datasets, respectively. In PN/NN, we identified four DEMs in the NTNU dataset and none in the Joyce dataset. However, when data was pooled for the meta-analysis, 20 DEMs were identified (Figure 1, ST. 4). Table 3 a-c shows the top 10 DEMs for each contrast in the meta-analysis.

\section{Correlation between datasets}

Shared DEMs in the two datasets were highly correlated (Pearson's correlation coefficient $r=0.89$ for $\mathrm{PP} / \mathrm{NN}, \mathrm{r}=0.87$ for PP/PN). Intersecting the DEMs showed substantial overlap (Figure 2a) and shared DEMs were mostly consistently expressed (Figure 2b). A total of 28 DEMs in PP/NN were exclusively identified in the meta-analysis and many of these were among the DEMs with the lowest $\log _{2}$ FC (Supplementary figure 1, ST. 5)

\section{Novel miRNAs}

To identify novel miRNAs in psoriatic skin we compared our results from the meta-analysis to previously published studies ${ }^{9-12,14}$. In total, we identified 131 novel miRNAs (ST. 6), corresponding to $33 \%$ of the DEMs in the meta-analysis.

\section{Biological functions}

To deduce the possible biological functions of the DEMs, targets of the miRNAs with average expression $\geq 100$ reads per million $(\mathrm{RPM})$ and $\mathrm{FDR}<0.05$ for $\mathrm{PP} / \mathrm{NN}$ and $\mathrm{PN} / \mathrm{NN}$ in the metaanalyzed data set were identified using TargetScan ${ }^{21}$. This threshold was chosen as most miRNAs below this threshold show no functional activity ${ }^{27.28}$. We are not presenting results from PP/PN, as these were similar to PP/NN. Predicted targets in PP/NN were enriched for several terms (Figure 3), 
medRxiv preprint doi: https://doi.org/10.1101/2021.01.27.21250590; this version posted January 29, 2021. The copyright holder for this preprint (which was not certified by peer review) is the author/funder, who has granted medRxiv a license to display the preprint in It is made available under a CC-BY-NC-ND 4.0 International license .

including 'Thyroid hormone signaling pathway', 'insulin resistance', 'human papillomavirus infection' and 'melanogenesis'. The most significantly enriched term for PP/NN and PN/NN was 'MicroRNAs in cancer'.

\section{Cell and tissue specific expression}

To evaluate which cells that express the top 10 up- and downregulated DEMs by FC in PP/NN and $\mathrm{PN} / \mathrm{NN}$, we extracted cell specific data from the FANTOM5 atlas ${ }^{26}$. In PP/NN DEMs were enriched in fibroblasts and epithelial cells, as well as in immune cells including monocytes and leukocytes (Figure 4). In PN/NN, several of the DEMs were enriched in epithelial and endo-epithelial cells (Figure 4).

Cell specific KEGG enrichment analysis showed that the enriched terms for each cell type were largely overlapping with the enriched terms for non-cell specific DEMs (Figures 3, 5). There was no clear separation of enriched terms between the different cell types.

\section{Psoriasis severity specific miRNAs}

We dichotomized the cases into mild (PASI <10) and moderate/severe (PASI $\geq 10$ ) and identified five DEMs in PP skin and six DEMs in PN skin. In PP skin, all five miRNAs were upregulated, while in PN skin, four miRNAs were upregulated and two were downregulated (ST. 7). The targets of the upregulated DEMs in PP and PN skin were enriched for inflammatory pathways including 'IL1signaling', 'transforming growth factor beta (TGF $\beta$ )-receptor complex' and toll-like receptor (TLR) cascades. The targets of the downregulated DEMs were enriched in mRNA processing pathways including splicing and translation. miR-374a and miR-146a were both upregulated in PP skin and these were enriched in myeloid leukocytes and hematopoietic cells (Figure 6). All DEMs in PN were depleted in leukocytes and hematopoietic cells.

\section{Discussion}

In this study, we explored the miRNAome in psoriatic skin by analyzing RNAseq data from 99 psoriatic cases and 66 controls, increasing the number of psoriatic cases four-fold from previous work. By improving statistical power due to a large sample, we identified 439 DEMs, of which 131 were novel and 11 were related to psoriasis severity. Further, we identified 20 DEMs between psoriatic non-lesional (PN) and healthy control skin (NN). This suggests an inherent change in all psoriatic skin, supporting the previously shown 'pre-inflammatory' signature outside established psoriatic plaques for protein-coding RNAs ${ }^{29}$. We identified enrichment of terms representing potential 
medRxiv preprint doi: https://doi.org/10.1101/2021.01.27.21250590; this version posted January 29, 2021. The copyright holder for this preprint (which was not certified by peer review) is the author/funder, who has granted medRxiv a license to display the preprint in It is made available under a CC-BY-NC-ND 4.0 International license .

disease pathology (e.g. 'Wnt-' and 'Ras signaling pathway') and established or emerging comorbidities (e.g. 'insulin resistance' and 'thyroid hormone signaling').

We replicated several of the most known miRNAs in psoriatic skin, including miR-21, miR-31 and miR-146a ${ }^{30}$. In PP/NN, miR-31-5p and mir-31-3p were the most differentially expressed by FC. miR31 has been shown to increase keratinocyte proliferation and migration and targets epithelial membrane protein $1(\mathrm{EMP}-1){ }^{31}$ and E2F transcription factor $2(\mathrm{E} 2 \mathrm{~F} 2)$, a known cell cycle regulator promoting proliferation ${ }^{32}$. miRNA-21, overexpressed in PP/NN, regulates keratinocyte proliferation and differentiation ${ }^{15}$ as well as T-cell apoptosis ${ }^{33}$. miR-128a was also highly upregulated in PP/NN. This miRNA is a regulator in Wnt-, and IL-23 signaling and is upregulated in peripheral blood neutrophils of patients with diffuse cutaneous systemic sclerosis ${ }^{34}$. This miRNA also targets genes involved in insulin signaling and may mediate some of the increased risk of insulin resistance and obesity in psoriasis ${ }^{35}$. While the majority of the DEMs were upregulated, some were downregulated, including miR-6510-3p $\left(\log _{2} \mathrm{FC}-2.23\right)$. This miRNA is also downregulated in oral lichen planus ${ }^{3637}$, an inflammatory and proliferative disease of the oral mucosa, as well as in squamous cell carcinoma ${ }^{37}$. Taken together, we have replicated known miRNAs in psoriasis and expanded the psoriatic miRNAome by identifying 131 novel DEMs.

The DEMs in PN/NN skin had lower FCs compared to PP/NN, however, they reflect inherent changes in all psoriatic skin and could play important roles in disease pathology. The upregulated miRNAs miR-34a-5p and miR-214-3p, target common genes (Figure 7) involved in cell cycle regulation and apoptosis. miR-34a has also been shown to promote keratinocyte inflammation ${ }^{38}$. Interestingly, three of the downregulated DEMs in PN/NN (miR-429, -200b and -141) are part of the miR-200 family. This miRNA family is highly expressed in skin and is central for skin homeostatic functions ${ }^{39}$. These miRNAs also have shared target genes (MALT1 and ZEB1) involved in NF-kB activation and signaling, as well as in T-cell receptor signaling. Our PN/NN results support the finding of an inflammatory and proliferative response in skin outside of established plaques ${ }^{29}$.

Enrichment analysis identified terms involved in well-known disturbed functions in psoriasis pathology. This included functions crucial for epidermal- and stem cell behavior and development ('Wnt signaling') ${ }^{40}$, epidermal proliferation and differentiation ('Ras signaling') ${ }^{41}$ and viral infections (e.g. 'human papillomavirus infection'). The term 'Hepatitis B' was significantly enriched for downregulated DEMs in PP/NN. This term contains genes important for TNF- and NF-kB signaling and leukocyte migration. Examples include CAMP responsive element binding protein 1 (CREB1), mitogen-activated protein kinase 8 (MAPK8), B-cell lymphoma 2 (BCL2) and phosphatidylinositol- 
medRxiv preprint doi: https://doi.org/10.1101/2021.01.27.21250590; this version posted January 29, 2021. The copyright holder for this preprint (which was not certified by peer review) is the author/funder, who has granted medRxiv a license to display the preprint in It is made available under a CC-BY-NC-ND 4.0 International license .

4,5-bisphosphate 3-kinase catalytic subunit alpha (PIK3CA), which are targets of 38, 26, 22 and 25 of the DEMs, respectively. This proposes these DEMs as mediators of inflammation regulation in psoriasis. Both within the melanogenesis and viral infection terms, there were also genes important for specific inflammatory processes associated with psoriasis, e.g. tumor necrosis factor (TNF) ${ }^{42}$, Th17-cell differentiation, and IL-17 signaling. Some of the genes are targets of many DEMs, including TGFBRI and MAPK1, targeted by 26 and 24 DEMs, respectively. Various cancer terms were also enriched for the downregulated miRNAs. These terms contain genes important for cell cycle and vascular endothelial growth factor (VEGF) signaling, e.g. PIK3CA, AKT serine/threonine kinase $(A K T) 3$ and cyclin dependent kinase $(C D K) 6$. These genes are targets of 25, 26 and 28 downregulated DEMs, respectively, suggesting that the miRNAs exert their functions through these target interactions. Some enriched pathways may also represent a shared molecular basis for psoriasis comorbidities, such as thyroid hormone signaling and insulin resistance.

'MicroRNAs in cancer' was the most significantly enriched term for both PP/NN and PN/NN. This term contains cell cycle regulators such as E2F3 and CDK6, potentially reflecting increased proliferation in both PP and PN skin. In PN/NN, the targets were enriched for pathways important for proliferation and inflammation, including 'MAPK-signaling' and 'ErbB-signaling', demonstrating inherent changes in all skin of psoriatic patients. Further, the downregulated miRNAs in PN/NN and PP/NN were enriched for 'axon guidance'. Axonal function has been recognized as an important factor in pruritus ${ }^{43}$, a symptom of psoriasis often overlooked.

In this study, we obtained full-thickness skin biopsies, containing a mixture of cell types, including keratinocytes, immune cells, fibroblasts and skin appendages. By extracting data from the FANTOM5 atlas ${ }^{26}$, we aimed to dissect the cell specific origin of the DEMs. The top DEMs in PP/NN were enriched in cell types important for skin structure, such as epithelial cells and fibroblasts and immune cells such as monocytes and leukocytes. We further aimed to elucidate the functions of the DEMs by cell type. Almost all cell types expressed miRNAs whose targets were enriched for insulin resistance, supporting the hypothesis of systemic inflammation and shared inflammatory pathways as the tie between psoriasis and metabolic syndrome/cardiovascular disease ${ }^{35}$. We acknowledge the limitations of using the FANTOM5 atlas for cell specific analysis as it is based on a limited set of non-inflamed skin samples. Further, our cell specific analyses focused on highly expressed miRNAs, which may downplay effects of miRNAs in rare cell types. To circumvent the dilution of lowabundant, but important transcripts, single-cell RNAseq (scRNA-seq) can be applied. scRNA-seq of a small number of psoriatic samples have identified the important role of endothelial cells expressing leukocyte adhesion molecules ${ }^{44}$ as well as trajectories for keratinocyte differentiation ${ }^{45}$. 
medRxiv preprint doi: https://doi.org/10.1101/2021.01.27.21250590; this version posted January 29, 2021. The copyright holder for this preprint (which was not certified by peer review) is the author/funder, who has granted medRxiv a license to display the preprint in It is made available under a CC-BY-NC-ND 4.0 International license .

Patients with severe psoriasis show a higher risk of comorbidities ${ }^{46}$ and the underlying molecular mechanisms may differ according to severity. We identified 11 DEMs comparing moderate/severe to mild psoriasis. The upregulated DEMs in both PP and PN skin were enriched for inflammatory pathways. The downregulated DEMs were enriched for pathways involved in mRNA processing, such as splicing and translation. This suggests that the upregulated DEMs reflect or respond to changes in immune function, while the downregulated DEMs are involved in more basic cellular functions. To determine if these changes are a cause or a consequence of increasing disease severity, functional studies are needed. Cell specific expression of the severity associated DEMs identified miRNAs enriched in both leukocytes and hematopoietic cells, suggesting that these migrate to the site upon plaque formation. Hematopoietic cells have been implicated in regulation of proliferating skin tissues during an early inflammatory phase ${ }^{47}$.

A major strength of this study is the large number of cases and controls. Our study provides insight into the effect of applying different statistical methods on gene expression data. The Joyce data (GSE31037) was originally analyzed using a Pearson's chi-squared test of goodness of fit on the normalized total reads from all PP, PN and NN skin ". To the best of our knowledge, this approach is not beneficial to identify significant expression differences between sample groups, as it ignores individual variation within each sample group and thereby inflates the significance of highly expressed genes with higher variation than lowly expressed genes ${ }^{19}$. We therefore reanalyzed the Joyce dataset which reduced the number of DEMs from the originally reported 317 to 257 (FDR $<0.05, \mathrm{FC}>1.4)$.

miRNA target prediction methods (including TargetScan), base predictions on statistically enriched sequence patterns in 3' UTRs for genes that are down- and upregulated in experiments where individual miRNAs are respectively up- and downregulated. Consequently, these methods identify hypothetical interactions between miRNAs and mRNAs. However, the relationship between miRNA expression and mRNA repression is not linear and depends on a variety of factors including sequence complementarity and alternative polyadenylation ${ }^{21,48}$. As such, the in vivo effects of endogenous miRNAs are difficult to predict reliably.

In conclusion, this study provides comprehensive insights into the miRNAome of psoriatic skin. By including a large sample of psoriatic cases and controls, we have identified 131 novel miRNAs for psoriasis, 11 miRNAs for psoriasis severity, and validated previously known psoriasis-associated miRNAs. We identified 20 DEMs in PN/NN, representing inherent alterations in the miRNAome of all skin of psoriatic patients. This advocates for the systemic involvement of the disease and may 
medRxiv preprint doi: https://doi.org/10.1101/2021.01.27.21250590; this version posted January 29, 2021. The copyright holder for this preprint (which was not certified by peer review) is the author/funder, who has granted medRxiv a license to display the preprint in It is made available under a CC-BY-NC-ND 4.0 International license .

represent shared molecular mechanisms of the systemic inflammation of psoriasis. Our study outlines future directions for targeted functional follow-up studies to explore the causal effects of the DEMs. Increased knowledge of the psoriasis transcriptome can prove crucial in understanding disease pathology, which can catalyze breakthroughs in the development of biomarkers for diagnostic purposes, predicting comorbidities and treatment response, as well as identifying treatment targets.

\section{Acknowledgements}

We are grateful to all the volunteers who contributed to our study as well as to assistance from staff at the Clinical Research Facility, St. Olavs hospital, Trondheim University Hospital, Norway and Biobank1, Trondheim, Norway. The total RNA extraction, library preparation and RNAseq were performed in close collaboration with the Genomics Core Facility (GCF), at the Norwegian University of Science and Technology (NTNU). The GCF is funded by the F. aculty of Medicine and Health Sciences at NTNU and Central Norway Regional Health Authority. This work was supported by the Liaison Committee between the Central Norway Regional Health Authority and NTNU.

\section{References}

1 Danielsen K, Olsen AO, Wilsgaard T et al. Is the prevalence of psoriasis increasing? A 30year follow-up of a population-based cohort. The British journal of dermatology 2013; 168: 1303-10.

2 Jensen P, Thyssen JP, Zachariae C et al. Cardiovascular risk factors in subjects with psoriasis: a cross-sectional general population study. Int J Dermatol 2013; 52: 681-3.

3 Modalsli EH, Snekvik I, Asvold BO et al. Validity of Self-Reported Psoriasis in a General Population: The HUNT Study, Norway. The Journal of investigative dermatology 2016; 136: $323-5$.

4 Michalek IM, Loring B, John SM. A systematic review of worldwide epidemiology of psoriasis. J Eur Acad Dermatol Venereol 2017; 31: 205-12.

5 Nair RP, Duffin KC, Helms C et al. Genome-wide scan reveals association of psoriasis with IL-23 and NF-kappaB pathways. Nat Genet 2009; 41: 199-204.

6 Bartel DP. MicroRNAs: genomics, biogenesis, mechanism, and function. Cell 2004; 116: 281-97.

7 Friedman RC, Farh KK-H, Burge CB et al. Most mammalian mRNAs are conserved targets of microRNAs. Genome Res 2009; 19: 92-105.

8 Sonkoly E, Wei T, Janson PC et al. MicroRNAs: novel regulators involved in the pathogenesis of psoriasis? PloS one 2007; 2: e610.

9 Zibert JR, Lovendorf MB, Litman T et al. MicroRNAs and potential target interactions in psoriasis. J Dermatol Sci 2010; 58: 177-85.

10 Lovendorf MB, Mitsui H, Zibert JR et al. Laser capture microdissection followed by nextgeneration sequencing identifies disease-related microRNAs in psoriatic skin that reflect systemic microRNA changes in psoriasis. Exp Dermatol 2015; 24: 187-93.

11 Joyce CE, Zhou X, Xia J et al. Deep sequencing of small RNAs from human skin reveals major alterations in the psoriasis miRNAome. Hum Mol Genet 2011; 20: 4025-40.

12 Delic D, Wolk K, Schmid R et al. Integrated microRNA/mRNA expression profiling of the skin of psoriasis patients. J Dermatol Sci 2020; 97: 9-20. 
medRxiv preprint doi: https://doi.org/10.1101/2021.01.27.21250590; this version posted January 29, 2021. The copyright holder for this preprint (which was not certified by peer review) is the author/funder, who has granted medRxiv a license to display the preprint in It is made available under a CC-BY-NC-ND 4.0 International license .

13 Chicharro P, Rodríguez-Jiménez P, Llamas-Velasco $\mathrm{M}$ et al. Expression of miR-135b in Psoriatic Skin and Its Association with Disease Improvement. Cells 2020; 9: 1603.

14 Srivastava A, Meisgen F, Pasquali L et al. Next generation sequencing identifies the keratinocyte-specific miRNA signature of psoriasis. The Journal of investigative dermatology 2019.

15 Liu Q, Wu DH, Han L et al. Roles of microRNAs in psoriasis: Immunological functions and potential biomarkers. Exp Dermatol 2017; 26: 359-67.

16 Griffiths-Jones S, Grocock RJ, van Dongen S et al. miRBase: microRNA sequences, targets and gene nomenclature. Nucleic Acids Res 2006; 34: D140-4.

17 Pantano L, Estivill X, Martí E. SeqBuster, a bioinformatic tool for the processing and analysis of small RNAs datasets, reveals ubiquitous miRNA modifications in human embryonic cells. Nucleic Acids Res 2010; 38: e34.

18 Ritchie ME, Phipson B, Wu D et al. limma powers differential expression analyses for RNA-sequencing and microarray studies. Nucleic Acids Res 2015; 43: e47.

19 Law CW, Chen Y, Shi W et al. voom: Precision weights unlock linear model analysis tools for RNA-seq read counts. Genome Biol 2014; 15: R29.

20 Benjamini Y, Hochberg Y. Controlling the False Discovery Rate: A Practical and Powerful Approach to Multiple Testing. Journal of the Royal Statistical Society. Series B (Methodological) 1995; 57: 289-300.

21 Agarwal V, Bell GW, Nam J-W et al. Predicting effective microRNA target sites in mammalian mRNAs. Elife 2015; 4: e05005.

22 Reimand J, Kull M, Peterson $\mathrm{H}$ et al. g:Profiler--a web-based toolset for functional profiling of gene lists from large-scale experiments. Nucleic Acids Res 2007; 35: W193-200.

23 Fabregat A, Sidiropoulos K, Viteri G et al. Reactome pathway analysis: a high-performance in-memory approach. BMC Bioinformatics 2017; 18: 142.

24 Fan Y, Siklenka K, Arora SK et al. miRNet - dissecting miRNA-target interactions and functional associations through network-based visual analysis. Nucleic Acids Res 2016; 44: W135-41.

25 Chang L, Zhou G, Soufan O et al. miRNet 2.0: network-based visual analytics for miRNA functional analysis and systems biology. Nucleic Acids Research 2020; 48: W244-W51.

26 Lizio M, Harshbarger J, Shimoji H et al. Gateways to the FANTOM5 promoter level mammalian expression atlas. Genome Biology 2015; 16: 22.

27 Mullokandov G, Baccarini A, Ruzo A et al. High-throughput assessment of microRNA activity and function using microRNA sensor and decoy libraries. Nat Methods 2012; 9: 840-6.

28 Bosson AD, Zamudio JR, Sharp PA. Endogenous miRNA and target concentrations determine susceptibility to potential ceRNA competition. Mol Cell 2014; 56: 347-59.

29 Tsoi LC, Rodriguez E, Degenhardt F et al. Atopic Dermatitis Is an IL-13-Dominant Disease with Greater Molecular Heterogeneity Compared to Psoriasis. The Journal of investigative dermatology 2019; 139: 1480-9.

30 Hawkes JE, Nguyen GH, Fujita M et al. microRNAs in Psoriasis. The Journal of investigative dermatology 2016; 136: 365-71.

31 Li D, Li XI, Wang A et al. MicroRNA-31 Promotes Skin Wound Healing by Enhancing Keratinocyte Proliferation and Migration. Journal of Investigative Dermatology 2015; 135: 1676-85.

32 Li T, Luo W, Liu K et al. miR-31 promotes proliferation of colon cancer cells by targeting E2F2. Biotechnol Lett 2015; 37: 523-32.

33 Meisgen F, Xu N, Wei T et al. MiR-21 is up-regulated in psoriasis and suppresses T cell apoptosis. Exp Dermatol 2012; 21: 312-4.

34 Li L, Zuo X, Liu D et al. The profiles of miRNAs and lncRNAs in peripheral blood neutrophils exosomes of diffuse cutaneous systemic sclerosis. Journal of Dermatological Science 2020; 98: 88-97. 
medRxiv preprint doi: https://doi.org/10.1101/2021.01.27.21250590; this version posted January 29, 2021. The copyright holder for this preprint (which was not certified by peer review) is the author/funder, who has granted medRxiv a license to display the preprint in It is made available under a CC-BY-NC-ND 4.0 International license .

35 Takeshita J, Grewal S, Langan SM et al. Psoriasis and comorbid diseases: Epidemiology. $J$ Am Acad Dermatol 2017; 76: 377-90.

36 Chen J, Du G, Wang Y et al. Integrative analysis of mRNA and miRNA expression profiles in oral lichen planus: preliminary results. Oral Surgery, Oral Medicine, Oral Pathology and Oral Radiology 2017; 124: 390-402.e17.

37 Nunez Lopez YO, Victoria B, Golusinski P et al. Characteristic miRNA expression signature and random forest survival analysis identify potential cancer-driving miRNAs in a broad range of head and neck squamous cell carcinoma subtypes. Reports of Practical Oncology \& Radiotherapy 2018; 23: 6-20.

38 Wu J, Li X, Li D et al. MicroRNA-34 Family Enhances Wound Inflammation by Targeting LGR4. Journal of Investigative Dermatology 2020; 140: 465-76.e11.

39 Hoefert JE, Bjerke GA, Wang D et al. The microRNA-200 family coordinately regulates cell adhesion and proliferation in hair morphogenesis. J Cell Biol 2018; 217: 2185-204.

40 Veltri A, Lang C, Lien WH. Concise Review: Wnt Signaling Pathways in Skin Development and Epidermal Stem Cells. Stem Cells 2018; 36: 22-35.

41 Drosten M, Lechuga CG, Barbacid M. Ras signaling is essential for skin development. Oncogene 2014; 33: 2857-65.

42 Wang CQF, Akalu YT, Suarez-Farinas M et al. IL-17 and TNF synergistically modulate cytokine expression while suppressing melanogenesis: potential relevance to psoriasis. The Journal of investigative dermatology 2013; 133: 2741-52.

43 Elias MS, Wright SC, Nicholson WV et al. Functional and proteomic analysis of a full thickness filaggrin-deficient skin organoid model. Wellcome Open Res 2019; 4: 134.

44 Reynolds G, Vegh P, Fletcher J et al. Poised cell circuits in human skin are activated in disease. bioRxiv 2020: 2020.11.05.369363.

45 Hughes TK, Wadsworth MH, 2nd, Gierahn TM et al. Second-Strand Synthesis-Based Massively Parallel scRNA-Seq Reveals Cellular States and Molecular Features of Human Inflammatory Skin Pathologies. Immunity 2020; 53: 878-94.e7.

46 Oliveira Mde F, Rocha Bde O, Duarte GV. Psoriasis: classical and emerging comorbidities. An Bras Dermatol 2015; 90: 9-20.

47 Kim WB, Jerome D, Yeung J. Diagnosis and management of psoriasis. Can Fam Physician 2017; 63: 278-85.

48 Afonso-Grunz F, Müller S. Principles of miRNA-mRNA interactions: beyond sequence complementarity. Cellular and Molecular Life Sciences 2015; 72: 3127-41. 
medRxiv preprint doi: https://doi.org/10.1101/2021.01.27.21250590; this version posted January 29, 2021. The copyright holder for this preprint (which was not certified by peer review) is the author/funder, who has granted medRxiv a license to display the preprint in It is made available under a CC-BY-NC-ND 4.0 International license

Table 1. Clinical characteristics of psoriatic cases and controls in the NTNU dataset.

\begin{tabular}{lcc}
\hline & Cases $(\boldsymbol{n}=75)$ & Controls $(\boldsymbol{n}=\mathbf{4 6})$ \\
\cline { 2 - 3 } Age, years (SD) & $52.7(16.0)$ & $38.9(15.4)$ \\
\hline Women, $n(\%)$ & $33(44.0)$ & $23(50.0)$ \\
\hline Height, $\mathrm{cm}(\mathrm{SD})$ & $174.2(9.1)$ & $176.9(8.9)$ \\
\hline Weight, $\mathrm{kg}(\mathrm{SD})$ & $86.4(16.2)$ & $78.3(14.9)$ \\
\hline BMI, $\mathrm{kg} / \mathrm{m}^{2}(\mathrm{SD})$ & $28.5(5.2)$ & $24.9(3.8)$ \\
\hline Waist circumference, $\mathrm{cm}(\mathrm{SD})$ & $100.3(15.8)$ & $89.4(12.0)$ \\
\hline PASI, $A U$ (SD) & $6.2(5.3)$ & - \\
\hline
\end{tabular}

$\mathrm{SD}$, standard deviation; cm, centimeter; kg, kilogram; BMI, body mass index; $\mathrm{m}$, meter; PASI, psoriasis area and severity index. 
medRxiv preprint doi: https://doi.org/10.1101/2021.01.27.21250590; this version posted January 29, 2021. The copyright holder for this preprint (which was not certified by peer review) is the author/funder, who has granted medRxiv a license to display the preprint in It is made available under a CC-BY-NC-ND 4.0 International license.

Table 2. Differentially expressed miRNAs $\left(\log _{2} \mathrm{FC}>0\right.$, FDR $\left.<0.05\right)$ between PP/NN, PP/PN and $\mathrm{PN} / \mathrm{NN}$ in the NTNU dataset, the Joyce dataset and the meta-analyzed dataset.

\section{Number of differentially expressed miRNAs}

\begin{tabular}{lccc} 
Contrast & NTNU & Joyce & Meta-analysis \\
\hline PP/NN & 375 & 231 & 395 \\
\hline PP/PN & 415 & 225 & 401 \\
\hline PN/NN & 4 & 0 & 20 \\
\hline
\end{tabular}

PP, lesional psoriatic skin; PN, non-lesional psoriatic skin; NN, healthy control skin 
medRxiv preprint doi: https://doi.org/10.1101/2021.01.27.21250590; this version posted January 29, 2021. The copyright holder for this preprint (which was not certified by peer review) is the author/funder, who has granted medRxiv a license to display the preprint in It is made available under a CC-BY-NC-ND 4.0 International license

Table 3. Top 10 differentially expressed miRNA by FC in the meta-analysis for (a) PP/NN, (b) $\mathrm{PP} / \mathrm{PN}$ and (c) $\mathrm{PN} / \mathrm{NN}$.

a)

\begin{tabular}{lccc}
\hline miRNA & Log $_{2} \mathrm{FC}$ & $P$-value & FDR \\
\hline hsa-miR-31-3p & 4.238 & $7.210 \times 10^{-31}$ & $1.668 \times 10^{-29}$ \\
hsa-miR-31-5p & 3.948 & $8.900 \times 10^{-51}$ & $9.469 \times 10^{-49}$ \\
hsa-miR-21-3p & 2.697 & $3.708 \times 10^{-82}$ & $1.973 \times 10^{-79}$ \\
hsa-miR-6510-3p & -2.227 & $4.538 \times 10^{-46}$ & $3.018 \times 10^{-44}$ \\
hsa-miR-1268a & 2.171 & $1.992 \times 10^{-26}$ & $2.864 \times 10^{-25}$ \\
hsa-miR-1268b & 2.157 & $5.653 \times 10^{-26}$ & $7.646 \times 10^{-25}$ \\
hsa-miR-885-5p & -2.144 & $5.247 \times 10^{-51}$ & $6.979 \times 10^{-49}$ \\
hsa-miR-940 & 2.129 & $6.437 \times 10^{-30}$ & $1.317 \times 10^{-28}$ \\
hsa-miR-3617-5p & -2.020 & $1.380 \times 10^{-25}$ & $1.669 \times 10^{-24}$ \\
hsa-miR-33b-3p & 1.972 & $1.983 \times 10^{-23}$ & $1.918 \times 10^{-22}$ \\
\hline
\end{tabular}

b)

c)

\begin{tabular}{lccc}
\hline miRNA & $\log _{2} \mathrm{FC}$ & $P$-value & FDR \\
\hline hsa-miR-31-5p & 3.799 & $1.471 \times 10^{-57}$ & $1.957 \times 10^{-55}$ \\
hsa-miR-31-3p & 3.719 & $7.753 \times 10^{-33}$ & $1.528 \times 10^{-31}$ \\
hsa-miR-21-3p & 2.603 & $6.084 \times 10^{-91}$ & $3.237 \times 10^{-88}$ \\
hsa-miR-3617-5p & -2.068 & $2.225 \times 10^{-30}$ & $3.199 \times 10^{-29}$ \\
hsa-miR-135b-5p & 1.949 & $7.824 \times 10^{-59}$ & $1.387 \times 10^{-56}$ \\
hsa-miR-33b-3p & 1.944 & $1.858 \times 10^{-30}$ & $2.746 \times 10^{-29}$ \\
hsa-miR-940 & 1.913 & $4.166 \times 10^{-34}$ & $9.234 \times 10^{-33}$ \\
hsa-miR-4517 & 1.906 & $5.583 \times 10^{-38}$ & $1.650 \times 10^{-36}$ \\
hsa-miR-664b-3p & -1.899 & $2.954 \times 10^{-54}$ & $2.619 \times 10^{-52}$ \\
hsa-miR-885-5p & -1.853 & $1.662 \times 10^{-46}$ & $1.263 \times 10^{-44}$ \\
\hline & & & \\
\hline miRNA & Log $2 \mathrm{FC}$ & $P$-value & FDR \\
\hline hsa-miR-6510-3p & -0.499 & $5.340 \times 10^{-5}$ & 0.004 \\
hsa-miR-598-3p & -0.428 & $2.352 \times 10^{-5}$ & 0.003 \\
hsa-miR-450a-5p & -0.411 & $1.708 \times 10^{-6}$ & $4.54 \times 10^{-4}$ \\
hsa-miR-214-3p & 0.373 & $2.747 \times 10^{-5}$ & 0.003 \\
hsa-miR-34a-5p & 0.355 & $1.199 \times 10^{-7}$ & $6.379 \times 10^{-5}$ \\
hsa-miR-141-3p & -0.343 & $1.517 \times 10^{-5}$ & 0.003 \\
hsa-miR-429 & -0.336 & $1.589 \times 10^{-4}$ & 0.009 \\
hsa-miR-574-5p & 0.334 & 0.001 & 0.028 \\
hsa-miR-542-3p & -0.304 & $1.639 \times 10^{-4}$ & 0.009 \\
hsa-miR-485-3p & 0.302 & $3.027 \times 10^{-4}$ & 0.015 \\
\hline hin PN, n0n-esionat &
\end{tabular}

PP, lesional psoriatic skin; PN, non-lesional psoriatic skin; NN, healthy control skin; FC, fold change. 
medRxiv preprint doi: https://doi.org/10.1101/2021.01.27.21250590; this version posted January 29, 2021. The copyright holder for this preprint (which was not certified by peer review) is the author/funder, who has granted medRxiv a license to display the preprint in It is made available under a CC-BY-NC-ND 4.0 International license .

\section{Figure Legends}

Figure 1. Box plot of expression levels of the six DEMs in PN/NN (meta-analysis) with reads per million $(\mathrm{RPM})>100$ in the NTNU and Joyce (GSE31037) data sets with $P$-values given for both separate and meta-analysis. These DEMs had small, but consistent expression levels across the datasets.

Figure 2 a) Venn-diagram showing overlap of the DEMs between datasets for PP/NN at FDR $<0.05$. A total of 155 (33\%) of DEMs were identified in all three datasets. b) Pie chart of the direction of fold change of the shared DEMs between all three datasets in PP/NN. Of the 155 DEMs, 151 (97\%) exhibit consistent expression patterns in the Joyce and NTNU datasets, and only four DEMs were inconsistently expressed.

Figure 3. Dot plot of the most significantly enriched KEGG pathways among the targets of up- and downregulated DEMs for PP/NN and PN/NN in the meta-analysis.

Abbreviations: Wnt, wingless-related integration site; Rap1, Ras-related protein 1; PI3K-Akt, phosphoinositide-3 kinase-akt; mTOR, mechanistic target of rapamycin; MAPK, mitogen-activated protein kinase; EGFR, epidermal growth factor; AMPK, AMP-activated protein kinase.

Figure 4. Primary cell expression analysis using the FANTOM5 atlas for the top 10 differentially expressed miRNAs (DEMs) in the meta-analysis in PP/NN and PN/NN. The miRNAs with an asterisk* were analyzed based on pre-miRNA, as the mature miRNA was not annotated.

Abbreviations: miRNA, micro RNA; GAG, glycosaminoglycan.

Figure 5. Enrichment analysis of DEMs by cell type showed a large overlap of enriched terms for up- and downregulated DEMs. Colors on the bottom bar indicate cell type and color on second bottom bar indicate direction of DEM regulation. Certain terms were only enriched for up-, and downregulated DEMs, including 'epidermal growth factor receptor (EGFR)', 'tyrosine kinase inhibitor resistance', 'thyroid hormone signaling pathway' and 'T cell receptor signaling pathway'. 'Hepatitis B' was only enriched for upregulated DEMs in leukocytes. Terms enriched in leukocytes were more significant as a group than the other cell types.

Abbreviations: TGF, transforming growth fatcor; PI3K-Akt, phosphoinositide-3 kinase-akt; mTOR, mechanistic target of rapamycin; JAK-STAT, janus kinase-signal transducer and activator of 
medRxiv preprint doi: https://doi.org/10.1101/2021.01.27.21250590; this version posted January 29, 2021. The copyright holder for this preprint (which was not certified by peer review) is the author/funder, who has granted medRxiv a license to display the preprint in It is made available under a CC-BY-NC-ND 4.0 International license.

transcription; FoxO, forkhead box transcription factor class O; EGFR, epidermal growth factor; ECM, extracellular matrix; cAMP, cyclic adenosine monophosphate; AMPK, AMP-activated protein kinase; AGE-RAGE, advanced glycation end products-receptor for advanced glycation end products; $\mathrm{CD}$, cluster of differentiation; OR, odds ratio.

Figure 6. Primary cell expression analysis using the FANTOM5-atlas for the DEMs identified in moderate/severe versus mild psoriasis. The miRNAs with an asterisk* were analyzed based on premiRNA, as the mature miRNA was not annotated.

Abbreviations: GAG, glycosaminoglycan; miRNA, micro RNA.

Figure 7. Upregulated miRNAs in PN/NN and their shared targets. Genes in green are part of the KEGG term 'pathways in cancer'. Target interactions and the illustration were created using miRnet ${ }^{2425}$. 
medRxiv preprint doi: https://doi.org/10.1101/2021.01.27.21250590; this version posted January 29, 2021. The copyright holder for this preprint (which was not certified by peer review) is the author/funder, who has granted medRxiv a license to display the preprint in perpetuity.

It is made available under a CC-BY-NC-ND 4.0 International license

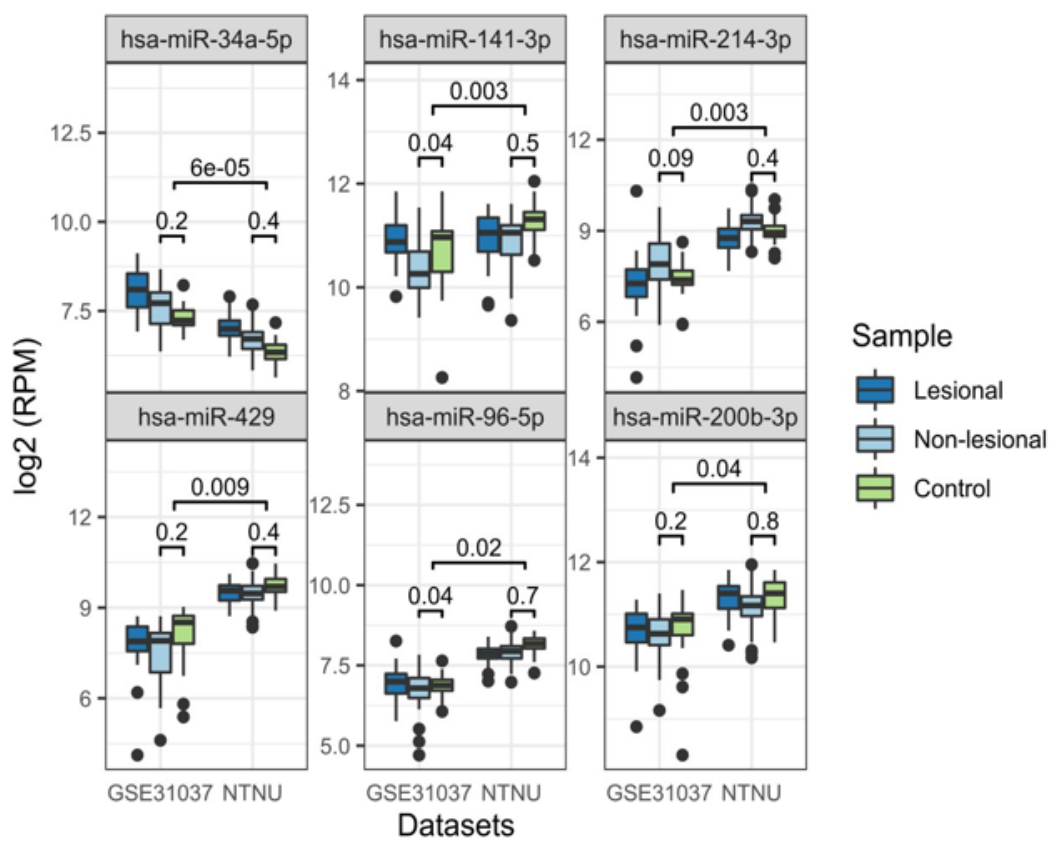

Figure 1 
medRxiv preprint doi: https://doi.org/10.1101/2021.01.27.21250590; this version posted January 29, 2021. The copyright holder for this preprint (which was not certified by peer review) is the author/funder, who has granted medRxiv a license to display the preprint in It is made available under a CC-BY-NC-ND 4.0 International license.

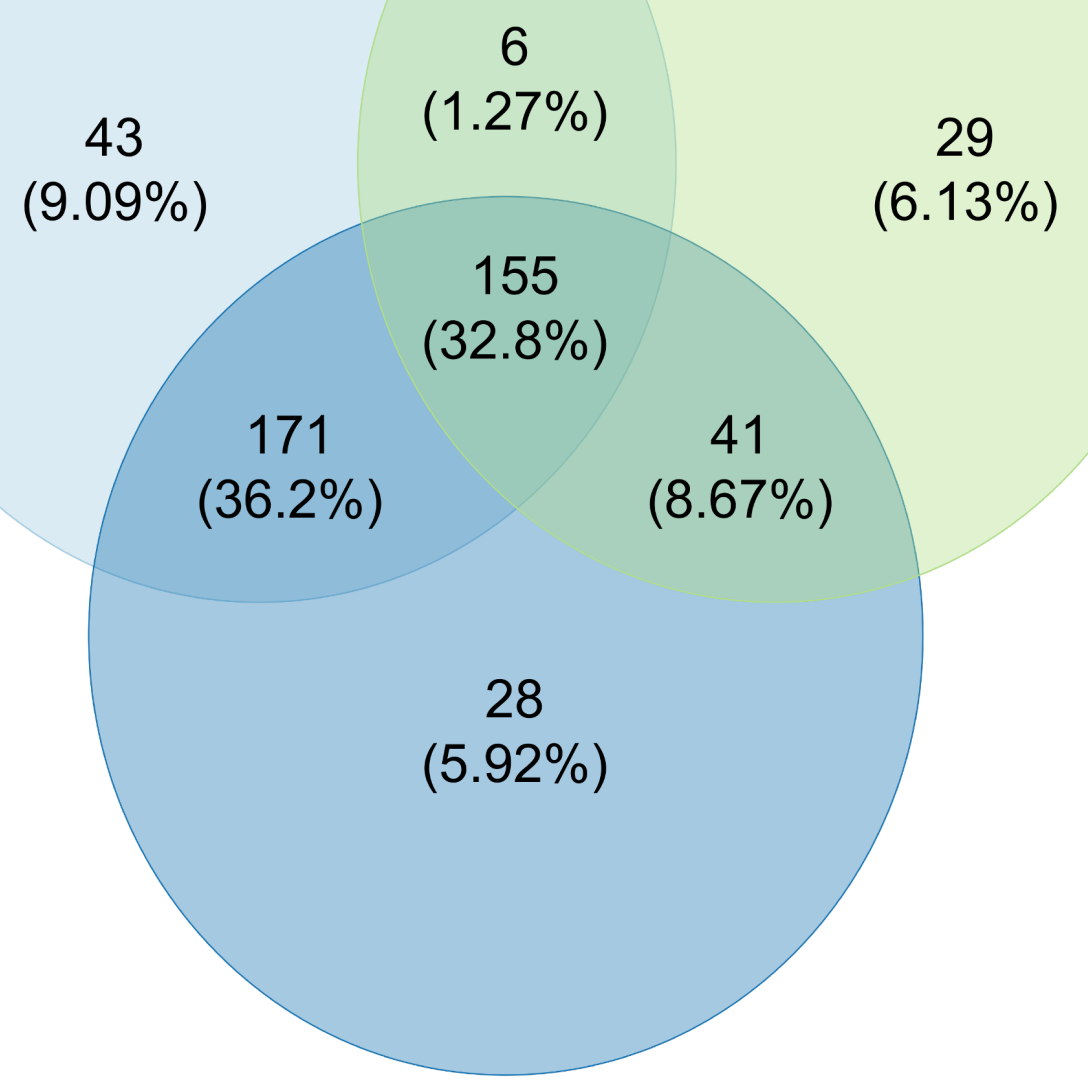

\section{Meta-analysis}


medRxiv preprint doi: https://doi.org/10.1101/2021.01.27.21250590; this version posted January 29, 2021. The copyright holder for this preprint (which was not certified by peer review) is the author/funder, who has granted medRxiv a license to display the preprint in It is made available under a CC-BY-NC-ND 4.0 International license.

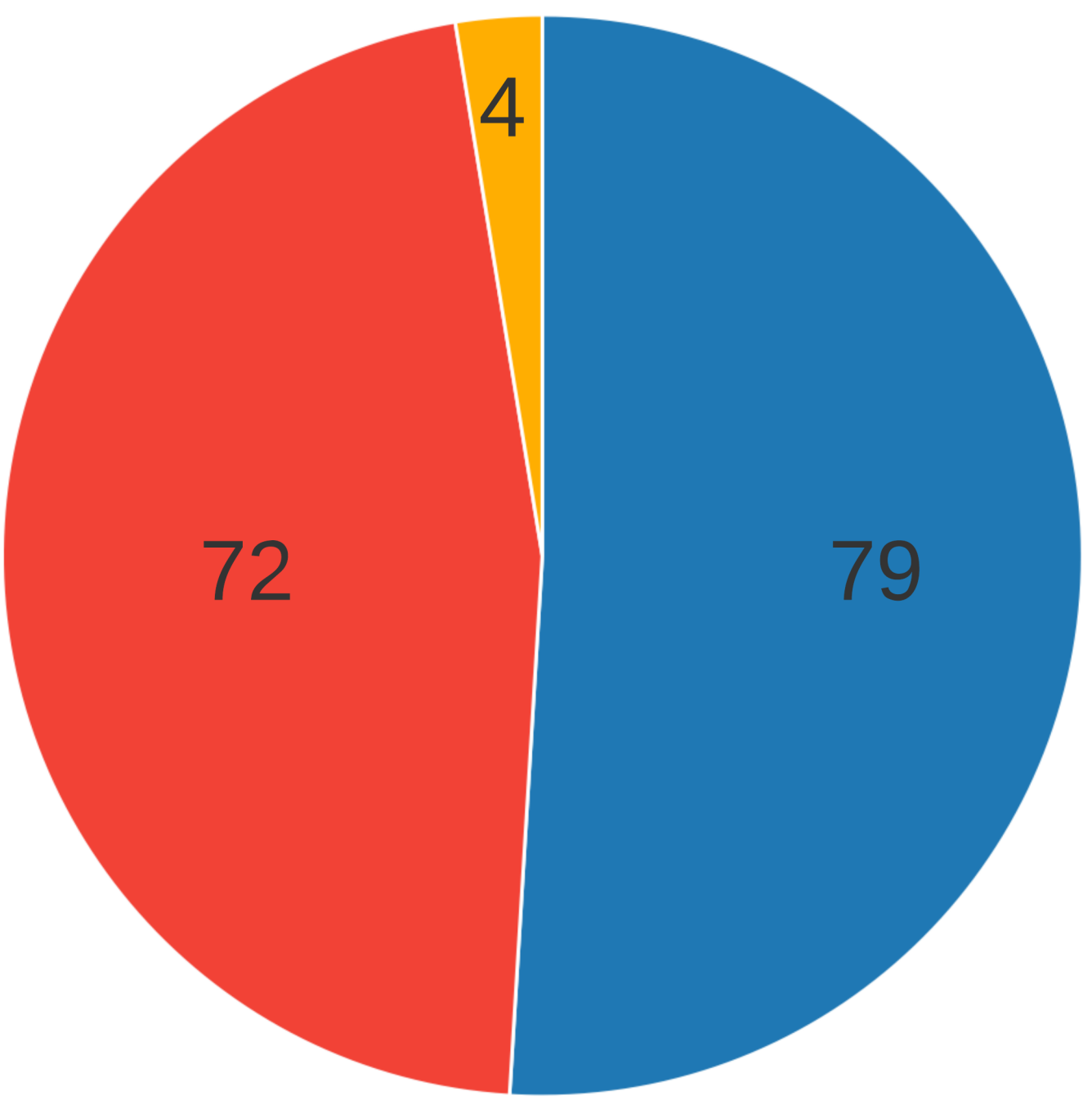

Upegulated in both datasets

Downregulated in both datasets Inconsistent expression

Figure $2 b$ 
medRxiv preprint doi: https://doi.org/10.1101/2021.01.27.21250590; this version posted January 29, 2021. The copyright holder for this preprint (which was not certified by peer review) is the author/funder, who has granted medRxiv a license to display the preprint in perpetuity.

It is made available under a CC-BY-NC-ND 4.0 International license .

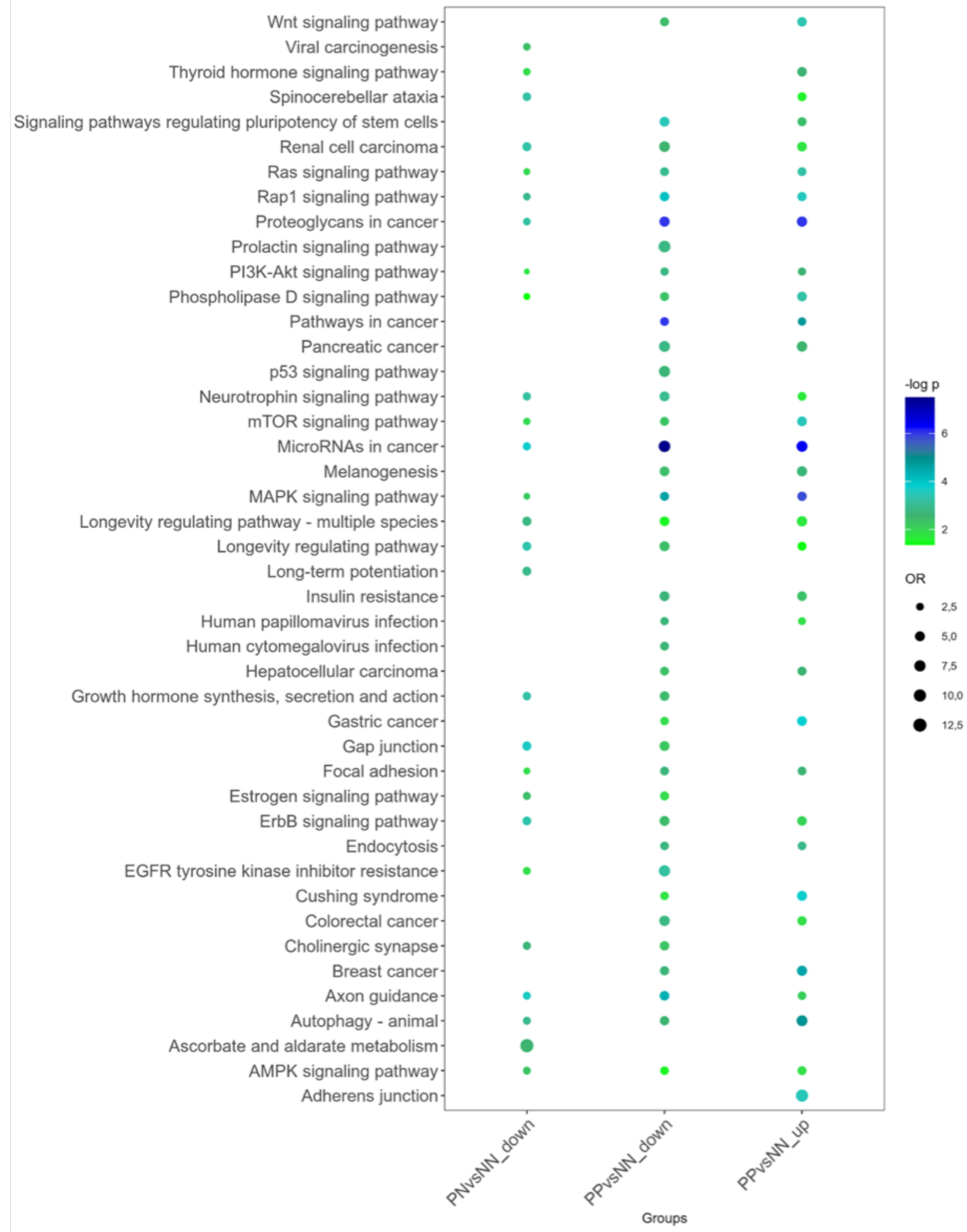

Figure 3 
medRxiv preprint doi: https://doi.org/10.1101/2021.01.27.21250590; this version posted January 29, 2021. The copyright holder for this preprint (which was not certified by peer review) is the author/funder, who has granted medRxiv a license to display the preprint in perpetuity.

It is made available under a CC-BY-NC-ND 4.0 International license .

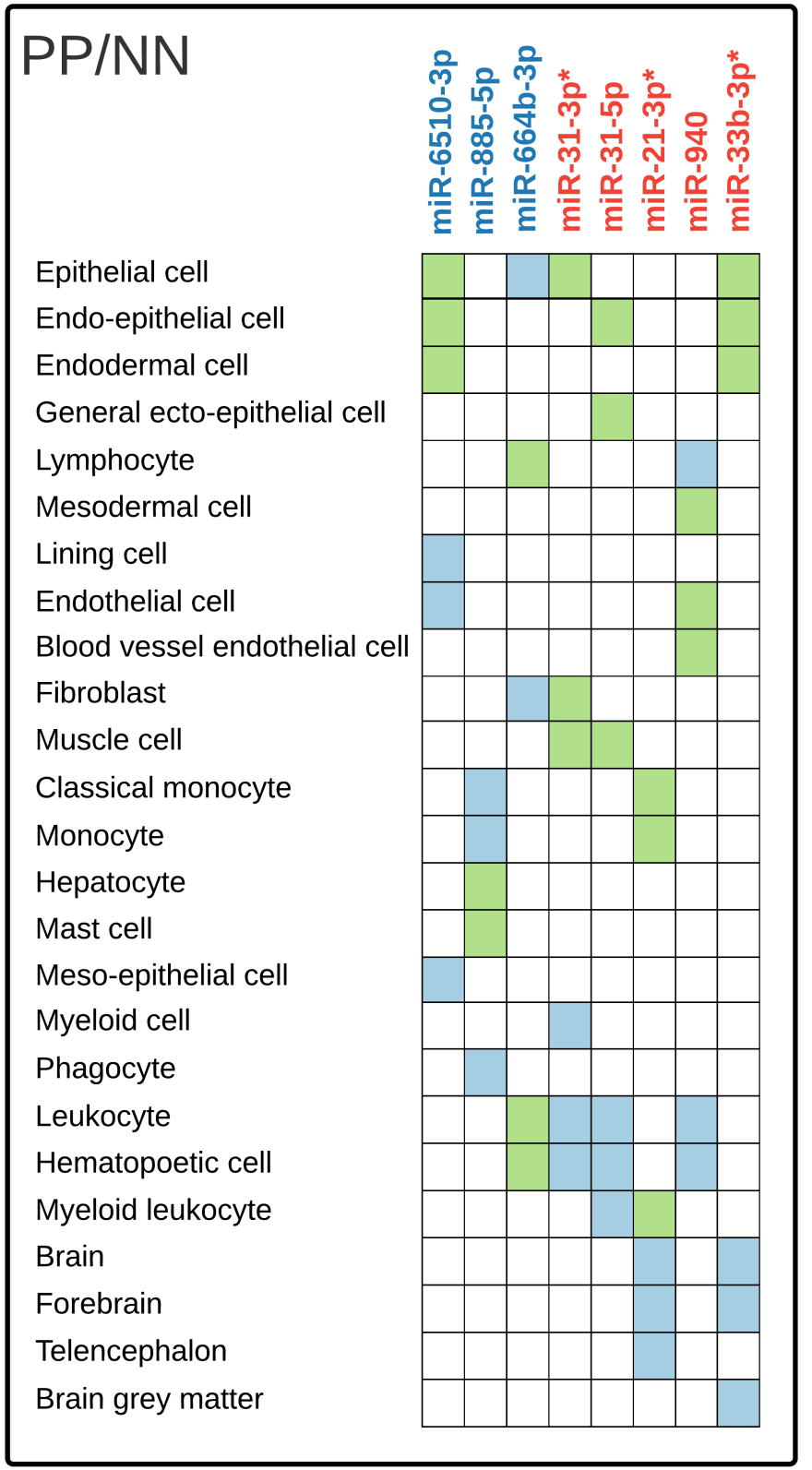

\section{PN/NN}

Epithelial cell

Endo-epithelial cell

Endodermal cell

Pluripotent stem cell

Lymphocyte

Mesodermal cell

Lining cell

Endothelial cell

Fibroblast

Muscle cell

Squamous epithelial cell

Aortic endothelial cell

Respiratory epithelial cell

Cell of skeletal muscle

Smooth muscle cell

Meso-epithelial cell

Preadipocyte

GAG secreting cell

Leukocyte

Hematopoetic cell

Myeloid leukocyte

Extraembryonic cell

Epithelial cell of amnion
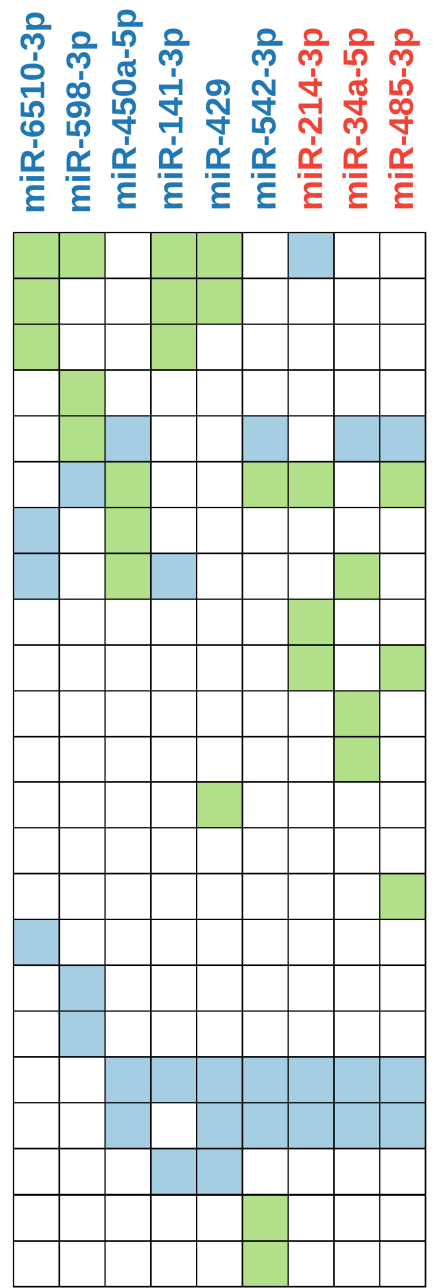

Enriched cells

Upregulated miRNA

Depleted cells

Downregulated miRNA

Figure 4 
medRxiv preprint doi: https://doi.org/10.1101/2021.01.27.21250590; this version posted January 29, 2021. The copyright holder for this preprint (which was not certified by peer review) is the author/funder, who has granted medRxiv a license to display the preprint in

It is made available under a CC-BY-NC-ND 4.0 International license .

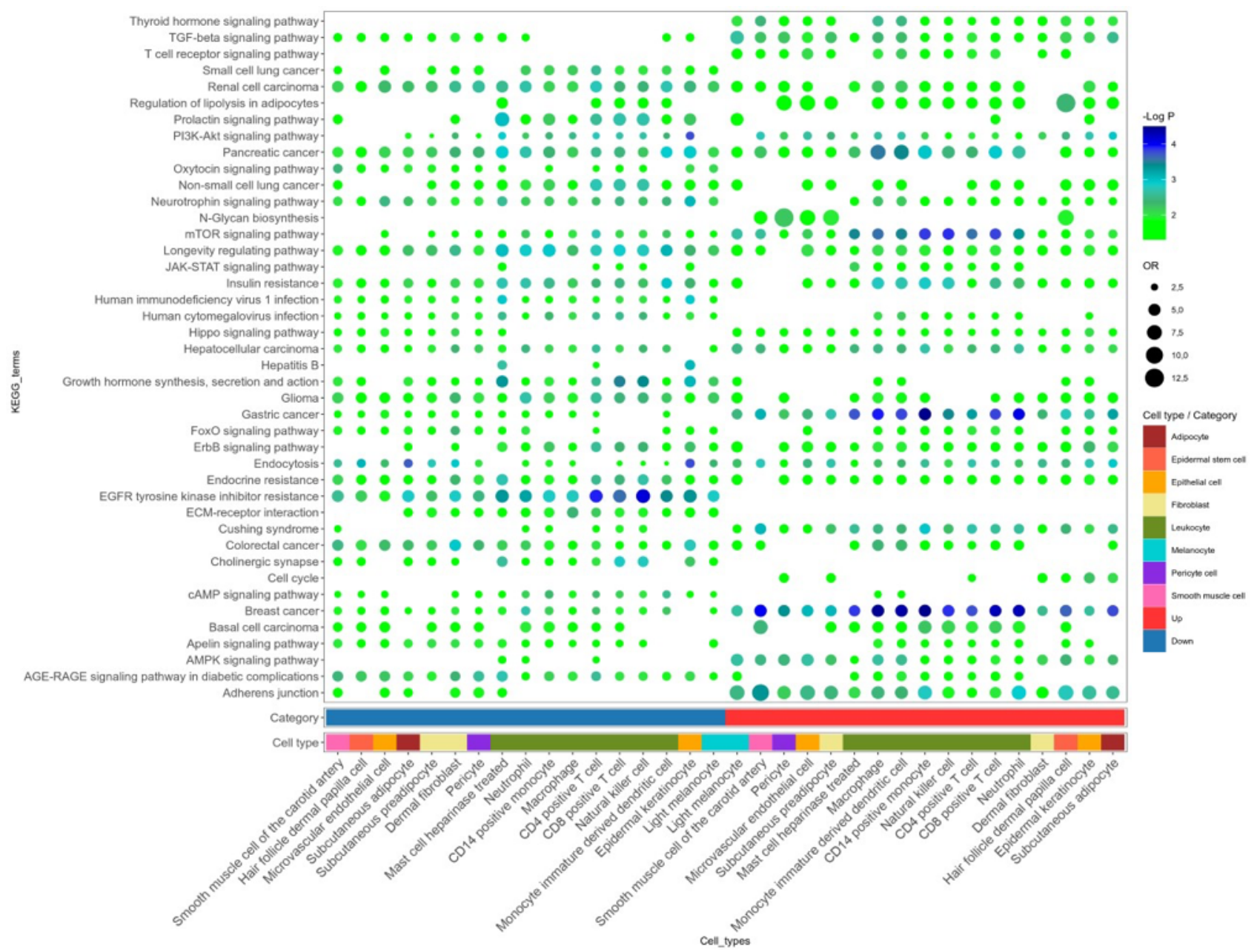

Figure 5 
Epithelial cell

Alfa-beta T cell

Leukocyte

Light melanocyte

Pigment cell

Mesodermal cell

Preadipocyte

Endothelial cell

Vein endothelial cell

Chondrocyte

Muscle cell

Cell of skeletal muscle

Smooth muscle cell

Myeloid leukocyte

Monocyte

Epithelial cell of lower respiratory tract

Respiratory epithelial cell

Pluripotent stem cell

Phagocyte

GAG secreting cell

Hematopoetic cell

Mesenchymal stem cells - umbillical

Mesenchymal stem cell

Brain

Neuroecto-epithelial cell

Neuroectodermal cell

Kidney epithelial cell

Renal cortical epithelial cell

Nephron tubule epithelial cell

Reproductive organ

Genitourinary system

Gonad
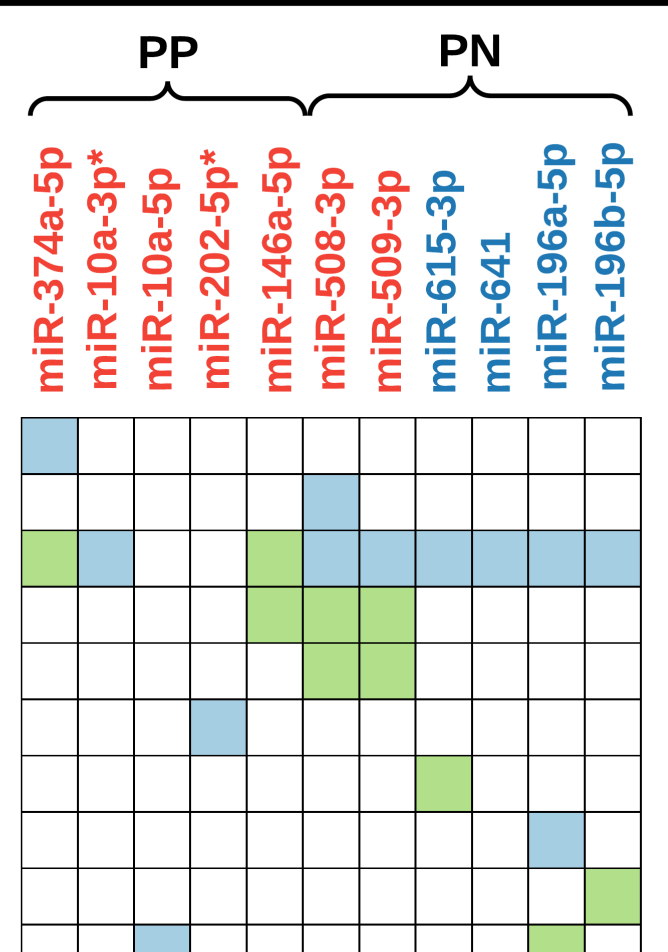

t
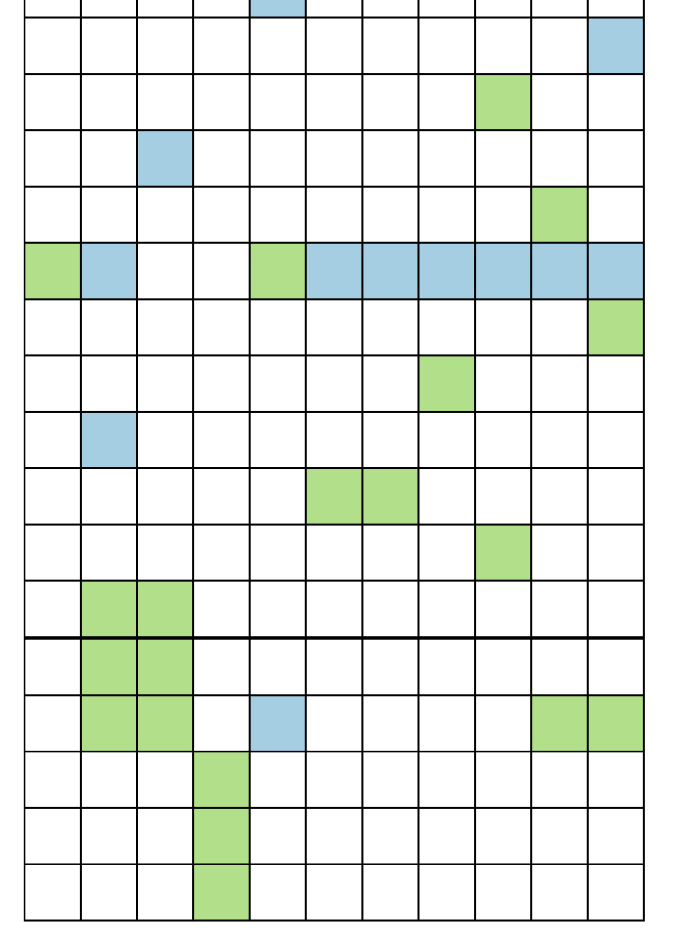

Upregulated miRNA

Downregulated miRNA 
medRxiv preprint doi: https://doi.org/10.1101/2021.01.27.21250590; this version posted January 29, 2021. The copyright holder for this preprint (which was not certified by peer review) is the author/funder, who has granted medRxiv a license to display the preprint in It is made available under a CC-BY-NC-ND 4.0 International license.

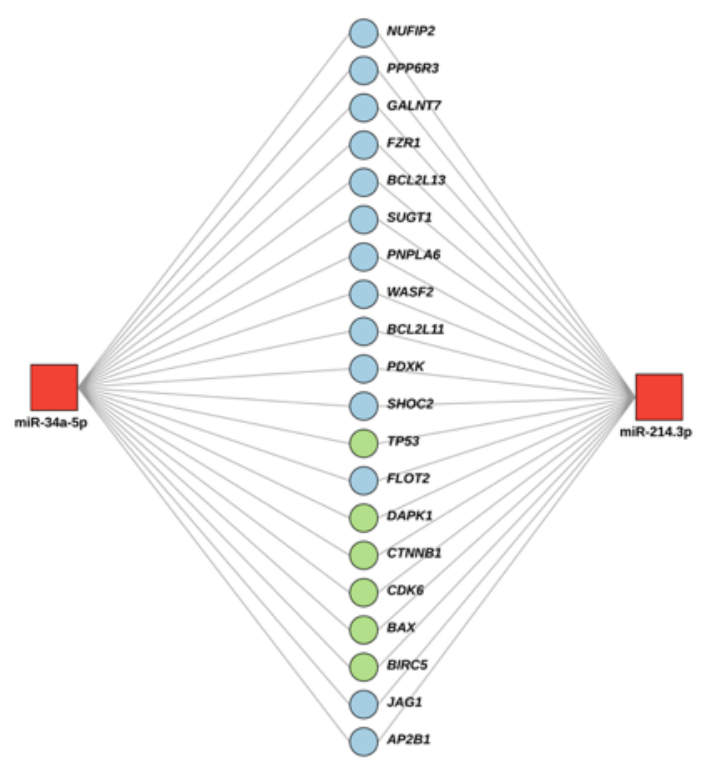

Figure 7 